\title{
New Inuit centre hopes to influence research agenda
}

Published at www.cmaj.ca on Jan. 26

$\mathrm{T}$ he director of Inuit Qaujisarvingat (pronounced kow-yee-sarving-at), the new Inuit Knowledge Centre, has already begun fielding calls from researchers anxious to incorporate traditional Inuit knowledge into their investigations of climate change, life and health in Canada's Arctic.

"I've been quite pleased with the interest from the research community," says Scot Nickels. "It's exciting."

Inuit Tapiriit Kanatami (formerly the Inuit Tapirisat of Canada) launched the centre in Ottawa, Ontario, in January to close the research gap involving the Inuit and Canada's Arctic. The centre, run from the national Inuit organization's Ottawa's headquarters, will promote Inuit-led research as well as collaborations among non-Inuit researchers and research institutes.

It was created to increase the amount of traditional knowledge that is evaluated during decision- and policymaking processes, says Nickels.

Inuit Tapiriit Kanatami President Mary Simon told a press conference announcing the centre's creation that "Inuit and Inuit communities have been studied by western scientists since the time of first contact - and some of those relationships have served us well. But the current processes and practices can be greatly improved."

The Inuit want to be "front and centre" in research that affects them, Simon added.

The centre, with an initial budget of about $\$ 300000$ for 2010, has begun offering training programs for Inuit research advisors, hopes to collaborate on academic research projects and act as a granting body to finance Inuit-specific projects, Nickels says.

Indian and Northern Affairs Canada provided seed money for the centre, which is now seeking funding from other potential partners, including universities and foundations.

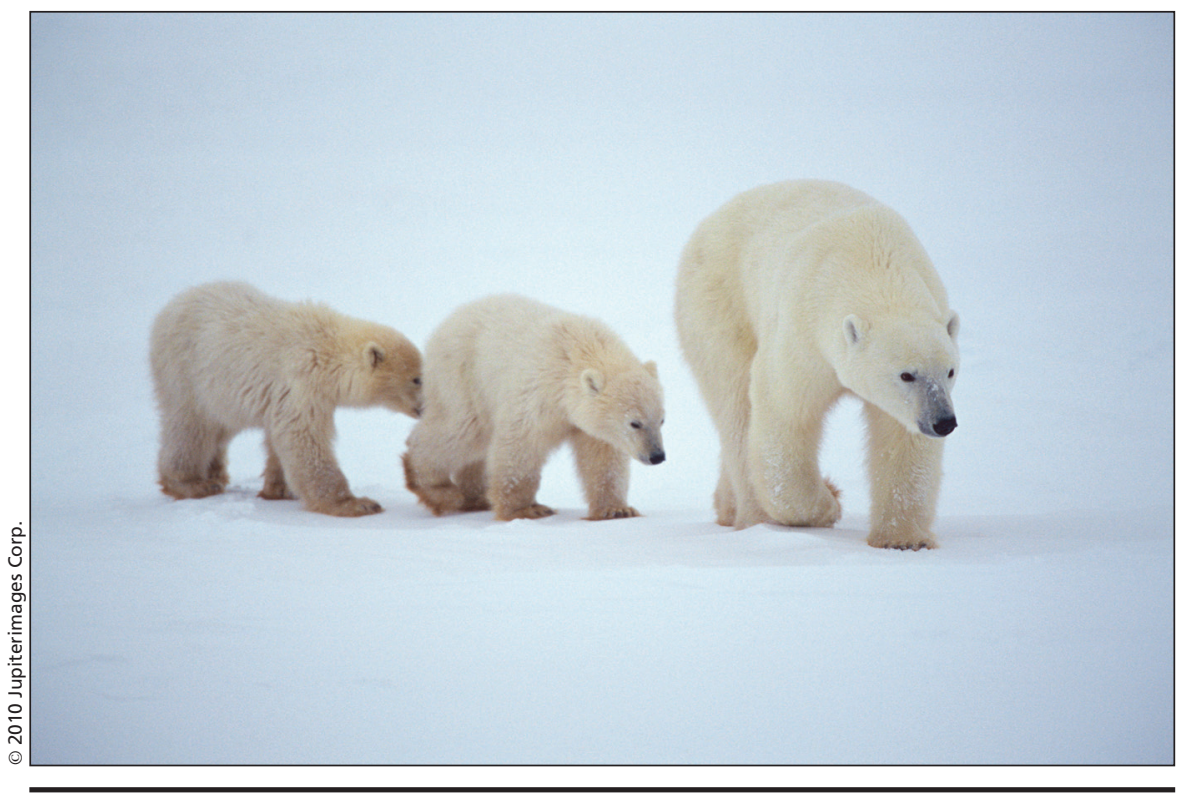

The controversy among Inuit and western researchers about the health of polar bear populations prompted the creation of the new Inuit Knowledge Centre, but the centre will also focus on incorporating traditional Inuit knowledge into research on climate change, life and health in Canada's Arctic.

The centre is already involved in projects looking at the effects of climate change on the Arctic, from an Inuit-specific perspective. In addition, it will be investigating food security issues, safety issues, changes in contaminant pathways and other health issues, Nickels says.

The centre also hopes to connect researchers from the south to existing regional Inuit institutes and to local experts with whom they might collaborate. It will also provide a boost to members of ArcticNet, a Network of Centres of Excellence in Canada that brings together researchers specializing in northern topics, says Russel Shearer, the chair of the network's research management committee.

"It gives researchers who have been pulling their hair out trying to make those connections and do integrated work a place to go as a starting point," Shearer says. "People are being turned inside out trying to figure out ways of working more collabora- tively with northern communities in science-based programs."

Shearer, who is also the director of Northern Science and Contaminants Research at Indian and Northern Affairs, expects the new centre will also boost his research program on the public health effects of chemical contamination in the Arctic, particularly with regard to the consumption of traditional foods.

"Working with the Inuit Knowledge Centre has the potential for helping our program tremendously in realizing all the implications and working more closely with the people involved," he says.

Although the Centre's genesis lies in the controversy among Inuit and western researchers about the health of polar bear populations in the North, that will not be its sole focus, the director emphasizes. "That is a key issue but it is not the only issue we would be looking at," Nickels says. - Laura Eggertson, Ottawa, Ont.

DOI:10.1503/cmaj.109-3168 